\title{
УДОСКОНАЛЕННЯ СТРАТЕГІЇ СТАЛОГО РОЗВИТКУ В СИСТЕМІ СТРАТЕГІЧНОГО МЕНЕДЖМЕНТУ ПІДПРИЄМСТВА
}

\author{
Харченко Тетяна Миколаївна \\ кандидат економічних наук \\ Сумський національний аграрній університет (м. Суми, Україна) \\ ORCID: 0000-0001-7260-1196 \\ Zirka-84@ukr.net
}

Стаття присвячена теоретичним та практичним питанням щодо сутності стратегічного управління. Висвітлено результати досліджень внутрішнього та зовнішнього середовища Сумської області, зокрема виявлено найбільш впливові фрактори, що формують сильні та слабкі сторони регіону, зроблено рейтинг за рівнем їх впливу. Здійснено стратегічний аналіз підприємств, графрічно відображено позиціювання сільськогосподарських підприємств Північно-Східного регіону в системі координат

Розглянуто варіанти стратегій, зокрема: стратегія інтеграції та диверсифікації, стратегія розвитку ринку та продукції, стратегія прориву, а також розглянуто бачення щодо формування майбутньої місії удосконалення стратегії сталого розвитку в системі стратегічного менеджменту підприємства.

Ключові слова: стратегічне управління, сталий розвиток, сільськогосподарське підприємство, менеджмент.

DOI: https://doi.org/10.32845/bsnau.2019.2.12

Постановка проблеми у загальному вигляді та її зв'язок із важливими науковими чи практичними завданнями. За умов нестабільності ринково-економічного зовнішнього середовища, досягти успіху в бізнесі можливо лише тоді, коли відбувається передбачення зміни, прогнозування наслідків та застосування антикризових заходів до них.

Стратегія підприємства є основою стратегічного планування, за допомогою якої на підприємстві знижується комплекс проблем, пов'язаних із цілеспрямованою переорієнтацією випуску продукції нової номенклатури й асортименту, впровадженням і використанням нових технологій, розвитку маркетингу, вдосконаленням структури керування підприємством, своєчасною та якісною підготовкою і перепідготовкою кадрів.

На сьогодні основні засади і підходи стратегічного управління в українських підприємствах запозичені переважно з розробок зарубіжних вчених і практики американських, японських і європейських корпорацій, з огляду на те, що досвід України у цій сфері невеликий. Тільки успішне оволодіння методами і підходами сучасного стратегічного управління з урахуванням ризику появи кризових ситуацій і його успішне впровадження дозволить підприємствам функціонувати стабільно та забезпечить їм позитивні перспективи. Науково-теоретична та практична значущість вказаних питань зумовила вибір теми, актуальність і цільову спрямованість дослідження.

Аналіз останніх досліджень і публікацій, у яких започатковано розв'язання даної проблеми і на які спирається автор, виділення невирішених раніше частин загальної проблеми, котрим присвячується означена стаття. Узагальнюючи наукові досягнення окремих етапів еволюції теорії стратегічного управління, можна стверджувати, що на сьогодні не існує єдиного концептуального бачення механізму та принципів формування стратегії як для підприємства, так і для забезпечення стабільного економічного розвитку галузей економіки в умовах сучасних реалій складних трансформаційних та інтеграційних корпоративних процесів.

Вагомий внесок у розвиток стратегічного управління зробили такі вчені: Андрєєв І. А. [1], Баценко Л.М. [2], Гавловська Н. І. [3], Гриньов А. В. [4], Донець Л. І. [5], Євчук Л. [6], Єрмакова О. М. [7], Зайцев Ю. О. [8], Киш Л.М. [9], Кобєлєв В. М. [10], Максименко Д.В. [11], Орлов В. М., [12], Петренко В. С. [13], Пузирьова, В. П. [14] та інші. Однак, залишається завжди актуальним дослідження щодо аналізу стратегічного управління підприємства в умовах ринкової економіки.

Формулювання цілей статті (постановка завдання). Метою даної статті є узагальнення поняття стратегічного управління, оцінка передумов розвитку Сумської області та стратегічне позиціюваня сільськогосподарських підприємств Північно-Східного регіону.

Виклад основного матеріалу. Стратегічне управління полягає у визначенні та виборі кращих напрямів і тенденцій розвитку сільськогосподарських підприємств, а також дієвих способів із встановлення та досягнення перспективних цілей у мінливих умовах зовнішнього середовища. Сучасними перевагами стратегічного управління для сільськогосподарського підприємства є: орієнтація діяльності на досягнення ринкового успіху; позиціювання на ринку з урахуванням майбутнього конкурентного стану; необхідність оцінки зовнішніх загроз та можливостей і вироблення відповідних заходів реагування на них.

Встановлено, що на даний час відсутнє єдине визначення стратегічного управління. Існує сукупність понять, у яких автори неоднозначно трактують об'єкти стратегічного управління, наголошуючи на різних їх аспектах та особливостях, що призводить до невизначеності поняття. Не заперечуючи актуальності, точності й акцентів, вважаємо, що стратегічне управління - це поетапне здійснення системи заходів активізації виробничої діяльності сільськогосподарських підприємств. Запропонована взаємодія стратегічного управління та стратегії підприємства, представлено на рис. 1. 


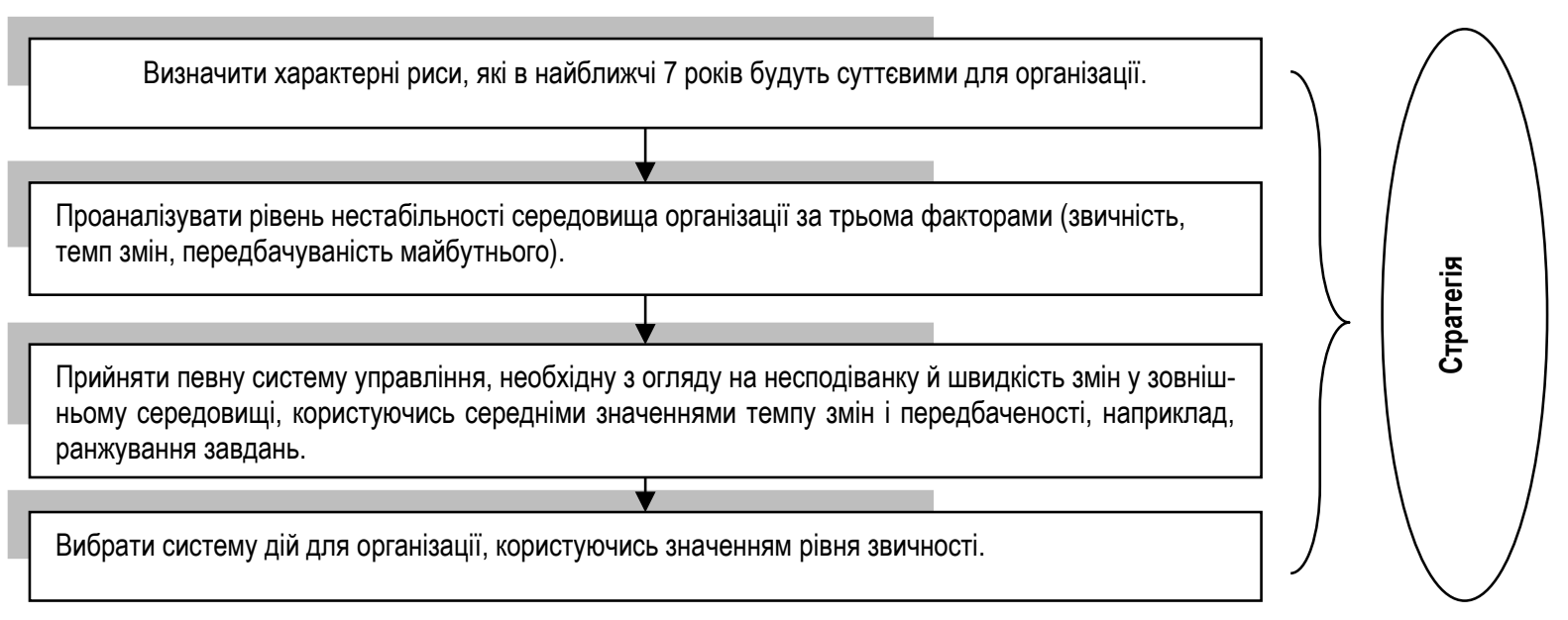

Рис. 1. Етапи вибору стратегії на підприємстві

Визначальним чинником стратегічного управління в умовах ринкової економіки є процес вибору стратегії. Він має ґрунтуватися на чіткій концепції розвитку аграрних підприємств, враховувати фактори, що визначають дії сільськогосподарських підприємств відповідно до обраних стратегій.

Стратегічний аналіз дозволяє визначити наявність внутрішніх ресурсів і засобів для використання зовнішніх можливостей за допомогою стратегічної діагностики та оцінки функціональних зон підприємства, виявити їх сильні та слабкі сторони.

Беручи до уваги єдину комплексну стратегію та план дій розвитку сільського господарства та сільських територій в Україні на 2015-2020 роки [16], результати проведених досліджень показали, що до найвпливовіших фракторів, які формують сильні сторони впливу Сумського регіону, відносять: стабільний розвиток та відносно висока продуктивність с/г галузі, наявність вільних земельних ділянок для ведення бізнесу та інвестування, наявність природних ресурсів (корисні копалини (нафта, газ), земельні, водні, лісові ресурси), наявність сировинної бази для подальшої переробки сільськогосподарської продукції. А відтік працездатного населення та молоді, особливо в сільській місцевості, низький рівень реальних доходів населення, високий рівень фізичного зносу основних фондів та застарілість технологій підкреслюють головні фактори слабких сторін SWOT- аналізу Сумської області.

На другому етапі було виконано рейтинг факторів за рівнем їх впливу. На третьому здійснено перехресний аналіз взаємозв'язків між факторами в секторах порівняльних переваг, викликів та ризиків, що дозволило сформувати систему цілей стратегії. Результати аналізу відображено в таблиці 1

Загрози та можливості

Таблиця 1

\begin{tabular}{|c|c|c|c|}
\hline Можливості & Рейтинг & Загрози & Рейтинг \\
\hline 1. Створення сприятливого інвестиційного клімату & 4,97 & $\begin{array}{l}\text { 1.Нестабільна ситуація в країні, у тому числі через ведення } \\
\text { військових дій }\end{array}$ & 5,53 \\
\hline $\begin{array}{l}\text { 2. Скорочення енергоспоживання через } \\
\text { впровадження енергоефрективних технологій }\end{array}$ & 4,68 & $\begin{array}{l}\text { 2. Зростання конкуренції для підприємств регіону через економічні } \\
\text { наслідки зближення з ЄС }\end{array}$ & 5,38 \\
\hline 3. Підвищення ефективності наукового потенціалу & 4,59 & 3.Демографічна та соціальна криза & 5,06 \\
\hline 4. Розвиток органічного землеробства & 4,53 & $\begin{array}{l}\text { 4.Підвищення вартості енергоносіїв та послуг житлово- } \\
\text { комунального господарства }\end{array}$ & 4,94 \\
\hline 5. Розвиток будівельної галузі & 4,47 & 5.Продовження деградації родючості ґрунтів & 4,91 \\
\hline 6. Розвиток ІТ-галузі & 4,45 & 6. Висока залежність від імпортного природного газу & 4,88 \\
\hline 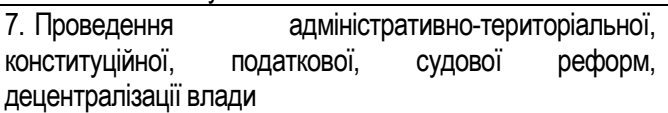 & 4,44 & $\begin{array}{l}\text { 7. Розбалансованість гілок влади, високий рівень корупції, прояви } \\
\text { політичного лобізму та низький рівень довіри до органів влади }\end{array}$ & 4,84 \\
\hline $\begin{array}{l}\text { 8. Запровадження зони вільної торгівлі між Україною та } \\
\text { країнами ЄС }\end{array}$ & 4,38 & 8. Наявність іноземних власників на стратегічних підприємствах & 4,84 \\
\hline $\begin{array}{l}\text { 9. Зростання обсягів пасажирських та вантажних } \\
\text { перевезень }\end{array}$ & 3,81 & 9. Монополія енергопостачальних структур & 4,75 \\
\hline 10. Розвиток туристичної індустрії & 3,72 & 10. Велика кількість контролюючих та фіскальних структур & 4,75 \\
\hline
\end{tabular}

Поєднання внутрішніх сильних сторін і зовнішніх загроз може призвести до занепаду вітчизняної аграрної науки стосовно розвитку тваринництва, експансії іноземного капіталу, технологій, обладнання, устаткування, ветеринарних профрілактичних та лікувальних засобів та ін. За таких умов доцільно посилити державну підтримку галузі, активізувати пошук внутрішніх інвесторів з інших галузей економіки. Найсприятливішим варіантом для розвитку підприємства у цій ситуації може стати стратегія інтеграції та диверсифікації. За- вдяки реалізації проектів вертикальної диверсифікації та інтеграції покращується використання засобів виробництва і трудових ресурсів, підвищується рівень незалежності від постачальників кормів і переробників продукції, покращується та стабілізується фінансовий стан, повніше задовольняється попит на продукцію [5]. Така стратегія дозволяє повніше насичувати ринок продукцією, нарощувати ефективність виробництва, сприяє зменшенню імпорту м'яса, збільшенню маси річного прибутку господарюючих суб'єктів, більшому надходженню доходів у держбюджет. 
В умовах поєднання внутрішніх слабких сторін та зовнішніх можливостей підприємства може відбутися посилення конкурентних переваг з боку іноземних виробників, горизонтальна інтеграція підприємств. На протидію негативним тенденціям рекомендується застосувати стратегію розвитку ринку та продукції. Така стратегія передбачає адаптацію підприємств до нових ринкових вимог, нових ринків збуту та форм продажу, підвищення якості продукції [9]. Стратегія розвитку ринку та виробництва продукції характеризується довгостроковими перспективами реалізації, високим комерційним ризиком та необхідністю значних витрат на дослідження каналів реалізації, розробку та впровадження заходів щодо підвищення якості про- дукції. Реалізація даної стратегії пов'язана передусім з посиленням ролі ринкових відносин, а соціальний та екологічний аспекти мають при цьому другорядне значення.

Формування і впровадження стратегії прориву потребує нових концепцій та способу мислення, нових «революційних» ідей та нової бізнес-культури. Здійснення такої стратегії передбачає значні витрати капіталу, часу, надання державної підтримки [11].

Визначення сутності ефективності стратегічного управління як відношення результату діяльності підприємства до його стратегічної мети проявляється в оцінці чистого прибутку та чистого доходу. Зокрема, спочатку варто проаналізувати в динаміці чистий прибуток та чистий дохід (таблиця 2)

Таблиця 2

Динаміка чистого доходу та чистого прибутку сільськогосподарських підприємств

Північно- Східного регіону, 2014-2018 рр.

\begin{tabular}{|c|c|c|c|c|c|c|c|}
\hline \multirow{2}{*}{ Показники } & \multicolumn{5}{|c|}{ Роки } & \multirow{2}{*}{$\begin{array}{l}\text { Абсолютне відхилення } \\
2018 \text { р. до } 2014 \text { р., +/- }\end{array}$} & \multirow{2}{*}{$\begin{array}{l}\text { Відносне відхилення } \\
2018 \text { р. до } 2014 \text { р., \% }\end{array}$} \\
\hline & 2014 & 2015 & 2016 & 2017 & 2018 & & \\
\hline Чистий дохід (тис. грн) & 2166,0 & 1741,6 & 1996,5 & 2676,5 & 3214,6 & 1048,6 & 148,4 \\
\hline Чистий прибуток (тис. грн) & 567,1 & 551,9 & 606,1 & 248,6 & 209,0 & $-358,1$ & 36,8 \\
\hline
\end{tabular}

Таким чином, із проведених розрахунків бачимо, що протягом п'яти років підприємство збільшило чистий дохід на $48 \%$, що становить 1048,6 тис. грн. за рахунок збільшення собівартості продукції. Проте, сума для підприємства $є$ незначною. У той же час, чистий прибуток підприємства зменшився у 2018 році проти 2014 року на 63,2 \% і становить
358,1 тис. грн. Це відбулося в наслідок нерентабельного рівня продукції, зростання її собівартості.

Також важливим напрямом оцінювання ефективності стратегічного управління підприємством виступає його позиціонування в певних зонах, які виділені в залежності від обсягів реалізації продукції підприємства (в грошовому виразі) та його прибутковості (рис.2).

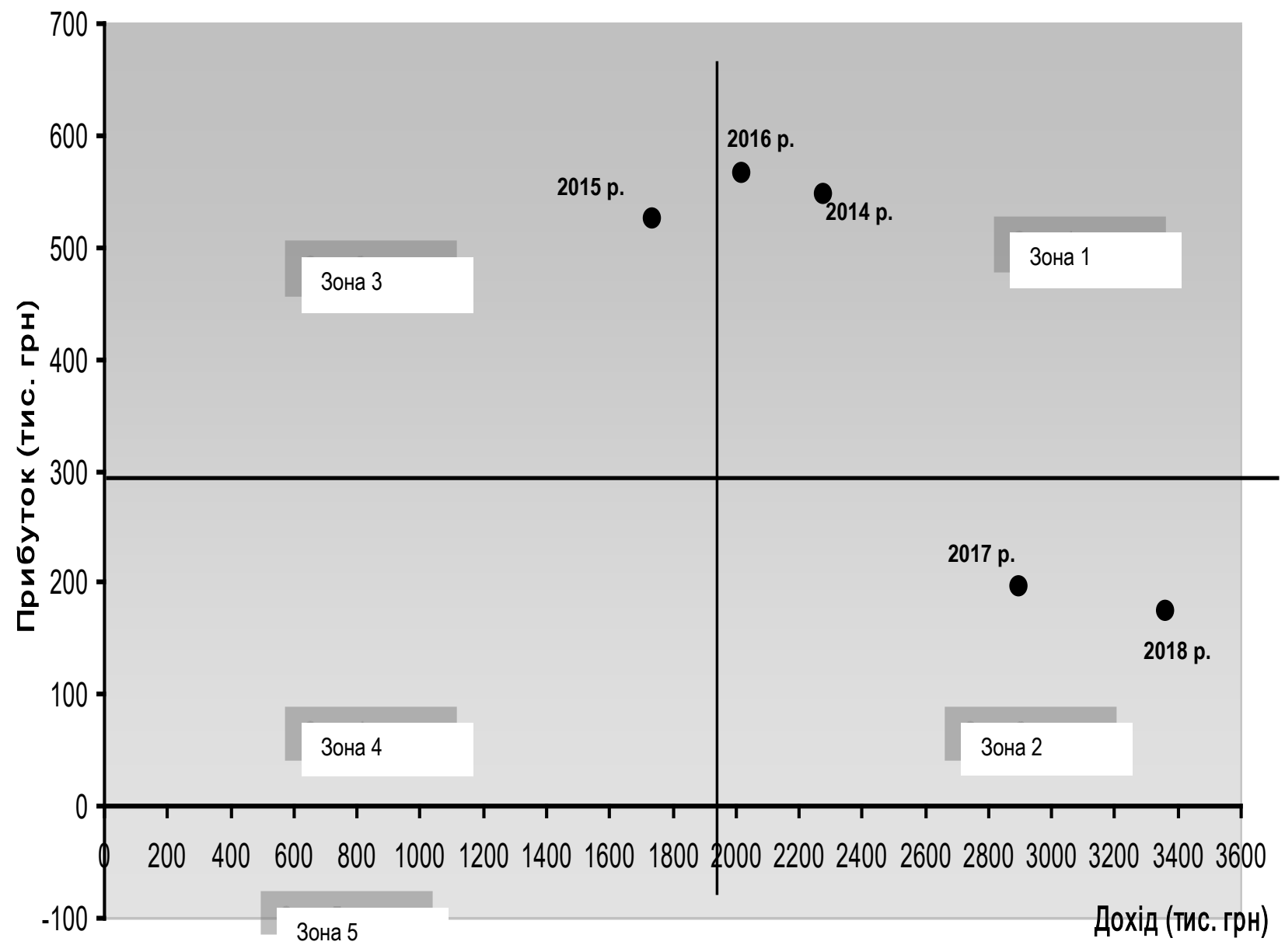

Рис.2. Зональний графік позиціонування сільськогосподарських підприємств Північно- Східного регіону в системі координат 2014-2018 pp. 
Графрік має 5 зон. Зона перша характеризує підприємство як лідера в обсягах доходу та обсягах прибутку. Цю зону підприємство зайняло в 2016 та 2014 роках за умов найкращих фінансових та ринкових позиції, що говорить про найвищий результат стратегічного управління.

Зона друга показує розміщення підприємства за панівними позиціями на ринку за обсягами доходу, в той час, коли рівень прибутку $є$ нижче середнього. Така ситуація у підприємства склалася у 2017-2018 рр. У такому разі, стратегія підприємства орієнтована на ринок і стратегічні дії спрямовані на утримання ринкових позицій або їх поліпшення.

В третю зону підприємство потрапило у 2015 році. За такої ситуації стратегічну мету визначають зростання прибутковості при незначних обсягах реалізованої продукції. Для даного підприємства пріоритетним були фрінансові стратегіï.

Зона четверта відображає позицію підприємства 3 низьким рівнем продажів та незначним чистим прибутком. Можна говорити, що в такому разі фактично стратегічне управління відсутнє. Головна мета такого підприємства - зберегти існуючі позиції і не втратити мінімальних сум прибутку. Як бачимо, підприємство не потрапило протягом досліджуваних років до даної зони.

У п'яту зону потрапляє підприємство, вразі збитків при невеликих обсягах реалізованої продукції. Підприємство характеризуються слабким внутрішнім потенціалом та нерозвиненістю застосованих ринкових механізмів.

Таким чином, формування місії й бачення підприємств галузі тваринництва у майбутньому базується на виділенні трьох стратегічних цілей: економічної - створення високоефективної галузі на засадах сталого розвитку, запровадження інноваційних ресурсозберігаючих та екологічно безпечних технологій; соціальної - задоволення потреб населення у споживанні продуктів харчування, підвищення якісних параметрів продукції; екологічної - зменшення негативного впливу відходів виробництва на екосистеми і використання альтернативних джерел енергії.

Реалізація стратегії сталого розвитку передбачає досягнення соціального вдоволення 3 приводу прийнятності продукції за ціною та якістю, модернізацію виробництва за параметрами, які відповідають найвищому ступеню віддачі вкладеного капіталу і найменшому ступеню руйнації екосистем. Сталий розвиток підприємств-виробників галузі тваринництва забезпечить синергетичний позитивний ефект в соціальній, економічній та природничій сфрерах.

Підсумовуючи вищевикладене, варто зауважити досить цікавий факт, що у стратегічному менеджменті провідних компаній все ширше застосовують принцип, в основу якого закладені знання, і відповідно квінтесенцію менеджменту складає стратегія знань. Саме знання в сучасних умовах виступають конкуренто утворюючим фактором, забезпечують ефективне впровадження стратегічного управління підприємством. У науковій літературі виділено п'ять базових стратегій знань. Першою визначено стратегію знань як бізнес-стратегію, за якої фокусування відбувається на створенні, використанні, розповсюдженні, оновленні знань з метою застосування їх на кожному етапі діяльності організації. Наступна - стратегія управління інтелектуальним капіталом - здійснює фрокусування на загально-організаційному рівні управління такими інтелектуальними активами, як патенти, технології та ін. Стратегія особистої відповідальності за знання - фокусування на персональній відповідальності кожного працівника за капіталізацію, оновлення та ефективне використання власних знань, за їх конкурентоспроможність. Далі виділена стратегія створення знань, яка базується на постійному поглибленні існуючих та генерації нових знань, що спрямовано на підвищення конкурентоспроможності підприємства. Стратегія трансферу знань полягає у системному підході до отримання, організації, реструктуризації та зберігання знань з метою їх ефективного використання [14].

Таким чином, удосконалення стратегії сталого розвитку в системі стратегічного менеджменту може бути визначена як довгостроковий план, який містить комплекс рішень щодо вибору напряму розвитку підприємства, визначення його основних цілей, а також моделі дій щодо формування та ефективного використання його потенціалу і дає можливість створення сприятливих внутрішніх та зовнішніх умов для успішного подолання основних стадій розвитку.

\section{Список літератури:}

1. Андрєєв І. А. Стратегічне управління та особливості організаційної поведінки персоналу сучасних організацій [Електронний ресурс] / І. А. Андрєєва // Науковий вісник Миколаївського державного університету імені В. О. Сухомлинського. Сер. : Психологічні науки. - 2013. - Т. 2, Вип. 10. - С. 20-24. - Режим доступу: http://nbuv.gov.ua/UJRN/Nvmdups 20132104

2. Баценко Л.М. Особливості стратегій розвитку на підприємствах сільського господарства/ Л.М.Баценко, А.С. Гузь/ «Проффесійний менеджмент в сучасних умовах розвитку ринку»: Матеріали доповідей VI науково-практичної конфееренції 3 міжнародною участю (1 листопада 2017 р.): Збірник. - Х.: Монограф. - 2017. - С. 209-211

3. Гавловська Н. І. Стратегічне управління підприємством: сучасний аспект [Електронний ресурс] / Н. І. Гавловська, €. М. Рудніченко // Наука й економіка. - 2015. - Вип. 1. - С. 110-114. - Режим доступу: http://nbuv.gov.ua/UJRN/Nie_2015_1_21

4. Гриньов А.В. Стратегічне управління в системі маркетинг менеджменту підприємств машинобудівного комплексу [Електронний ресурс] / А. В. Гриньов // Вісник Національного технічного університету "ХПІ". Технічний прогрес та еффективність виробництва. - 2015. - № 46. - С. 92-96. - Режим доступу: http://nbuv.gov.ua/UJRN/Vcpitp_2015 4613

5. Донець Л. І. Стратегічне планування як базова складова стратегічного управління малими підприємницькими структурами / Л. І. Донець, І. В. Давидюк // Вісник Запорізького національного університету (Серія “Економічні науки"). —2010. — № 4(8). - C. 19.

6. Євчук Л. Роль стратегій зростання в забезпеченні конкурентоспроможності сільськогосподарських підприємств / Л.Євчук // Економіст. - 2014. - №9. - С.14-17.

7. Єрмакова О. М. Стратегічне управління підприємством: сутність та особливості / О.М. Єрмакова // Науковий вісник Полісся. - 2016 - № 4. - С. 92- 96. 
8. Зайцев Ю. О. Механізм стратегічного управління аграрних підприємств / Ю. О. Зайцев // Вісник Харківського національного аграрного університету. Серія «Економічні науки». - № 2. - 2016. - С. 212-219.

9. Киш Л.М. Стратегічне управління як основна частина менеджменту підприємства / Л. М. Киш // Причорноморські економічні студії. Економіка та управління підприємствами. - 2019. - Випуск 38-1. - С. 107-113.

10. Кобєлєв В. М. Теоретичні та методологічні основи фрормування стратегії розвитку підприємства / В. М. Кобєлєв, Ю. В. Захарченко //Вісник економіки транспорту і промисловості. - 2013. - № 42. - С. 297-303.

11. Максименко Д.В. Розвиток стратегічного управління на підприємствах аграрного сектору / Д.В. Максименко // Молодий вчений».- № 4 (19) Ч. 1 .- 2015. - С. 112-115.

12. Орлов В. М. Стратегічне планування в процесі управління підприємством / В. М.Орлов, С. С. Новицька // Зовнішня торгівля: економіка, фінанси, право : наук. журнал (Серія “Економічні науки"). - 2015. - № 1(78).- С. 106.

13. Петренко В. С. Розвиток стратегій управління спільними підприємствами / В.С. Петренко // Херсонський державний університет «Young Scientist». - 2018. - № 1 (53). - С. 525-528.

14. Пузирьова, В. П. Матриця ключових стратегій в управлінні фінансовим потенціалом промислових підприємств / В. П. Пузирьова // Актуальні проблеми економіки. - 2014 - № 6. - С. 152.

15. Єдина комплексна стратегія та план дій розвитку сільського господарства та сільських територій в Україні на 20152020 роки [Електронний ресурс]. - Режим доступу: http://minagro.gov.ua/node/16025

Kharchenko T.M, PhD, Sumy National Agrarian University (Sumy, Ukraine)

Improvement of the strategy of sustainable development in the system of strategic management of the enterprise

The article is devoted to theoretical and practical questions about the essence of strategic management. The results of research of the internal and external environment of the Sumy region are presented, in particular, the most influential factors that form the strengths and weaknesses of the region are identified, a rating is made by the level of their impact.

Options for strategies are considered, including: integration strategy and diversification, market and product development strategy, breakthrough strategy, and the vision of forming the future mission of improving the strategy of sustainable development in the enterprise strategic management system

Keywords: strategic management, sustainable development, agricultural enterprise, management.

Дата надходження до редакції: 27.01.2019 р. 